\title{
СТАН СИСТЕМИ ПРОТЕЇНАЗИ/ІНГІБІТОРИ ПРОТЕЇНАЗ У ЩУРІВ У ДИНАМІЦІ ІММОБІЛІЗАЦІЙНОГО СТРЕСУ НА ТЛІ ГІПОТИРЕОЗУ
}

Вступ. У патогенезі багатьох патологічних станів важливе місце посідають порушення протеїназо-інгібіторної системи. При відсутності належного контролю за протеолізом розвиваються патологічні стани, що супроводжуються виникненням деструктивних, запальних та імунних реакцій. Ряд дослідників встановив захисну дію йодовмісних тиреоїдних гормонів при стресі, які реалізуються в результаті їх взаємодії з клітинним геномом, що призводить до стимуляції локальних стрес-лімітуючих систем.

Мета дослідження - встановити особливості фрункціонування системи протеїнази/інгібітори протеїназ за умов іммобілізаційного стресу на тлі зниження рівня йодовмісних гормонів щитоподібної залози.

Mетоди дослідження. Гіпотиреоз моделювали, щоденно вводячи тваринам per os muреостатик мерказоліл (“Здоров'я”, Україна) у дозі 25 мг/кг протягом 21-ї доби. Гострий іммобілізаційний стрес моделювали шляхом прив'язування піддослідних щурів у положенні на спині за 4 кінцівки без обмеження рухомості голови тривалістю 3 год. Для дослідження концентрації йодовмісних гормонів щитоподібної залози, активності протеїназної системи і вмісту інгібіторів протеолізу використано спектрофотометричні та імунофрерментні методи.

Результати й обговорення. Досліджено вплив іммобілізаційного стресу в щурів з попередньо змодельованим гіпотиреозом на показники протеїназо-інгібіторної системи крові. На стадії тривоги розвитку стрес-реакції в евтиреоїдних тварин встановлено підвищення протеолітичної активності крові на тлі збільшення вмісту $\alpha_{1}$-інгібітора протеаз та $\alpha_{2}$-макроглобуліну, що вказує на посилення антипротеолітичного потенціалу для стримування розвитку деструкції. На стадії резистентності відбувалася стабілізація протеолітичної активності крові. Однак при тривалому стресі (стадія виснаження) вона знову достовірно зростала на тлі зниження активності інгібіторів протеаз, що свідчить про виснаження захисного інгібіторного резерву. У тварин з гіпотиреозом на всіх стадіях розвитку стрес-реакції мало місце достовірне підвищення протеолітичної активності крові, причому показники інгібіторів протеаз достовірно зменшувалися. Це призводило до різкого зростання індексу протеолізу, що відбувалося на тлі збільшення проникності лізосомальних мембран.

Висновок. На тлі гіпотиреозу спостерігають інтенсивніше, ніж у евтиреоїдних тварин, зростання протеолітичної активності крові на фроні пригнічення антипротеазної активності та збільшення проникності лізосомальних мембран.

КЛЮЧОВІ СЛОВА: стрес; гіпотиреоз; протеїназо-інгібіторна система; лізосомальні мембрани.

ВСТУП. У патогенезі багатьох патологічних станів важливе місце посідають порушення протеїназо-інгібіторної системи [1-3]. Процеси лімітованого (обмеженого) протеолізу відіграють важливу роль в утворенні з неактивних попередників активних орорм срерментів, гормонів, структурних білків, білків плазми крові, утворенні та інактивації біоактивних пептидів (кініни, нейропептиди), що беруть участь у регуляції судинного тонусу, процесів мікроциркуляції, фрункції мозку тощо [1].

При відсутності належного контролю запротеолізом розвиваються патологічні стани, що супроводжуються виникненням деструктивних,

(с) О. Є. Любович, І. М. Кліщ, А. С. Вольська, Х. І. Курило, 2018. запальних та імунних реакцій. Різноманітний спектр фізіологічної дії протеїназ, їх висока активність стосовно білкових субстратів зумовлюють складність механізмів регуляції цих процесів в організмі [3, 4]. Біологічна активність протеолітичних ферментів визначається концентрацією ферменту й субстрату, pH, іонною силою і температурою. Проте вміст у крові та тканинах специфрічних білків ( $\alpha_{1}$-інгібітора протеїназ $\left(\alpha_{1}-І П\right), \alpha_{2}$-макроглобуліну ( $\left.\alpha_{2}-\mathrm{MГ}\right)$, антитромбіну III, $\alpha_{2}$-антиплазміну, $\alpha_{1}$-антихімотрипсину тощо), які утворюють комплекси з протеїназами, є однією 3 найбільш важливих ланок контролю за протеолізом [1, 5, 6].

За фрізіологічних умов активність протеолітичних фрерментів урівноважена з рівнем інгібі- 
торів протеїназ. При критичних станах порушується динамічна рівновага між протеазами та їх інгібіторами. Збільшення кількості та активності фрерментів протеолізу тканинного походження призводить до “протеазного вибуху”, у зв'язку з чим гіперактивуються згортальна, фрібринолітична, калікреїн-кінінова, ренін-ангіотензин-альдостеронова системи і комплемент. Викликані зміни зумовлюють розвиток деструктивних і запальних змін у всьому організмі $[1,3,7]$.

За дії різних патогенних чинників спостерігають значне підвищення активності протеолітичних фрерментів, і вони з фрактора регуляції перетворюються на чинник пошкодження $[1,8]$. Однією з причин, які зумовлюють цю транссрормацію, є зниження активності ендогенних інгібіторів протеїназ і збільшення проникності лізосомальних мембран [9, 10].

Найбільш розповсюдженими серед протеолітичних фрерментів $€$ серинові протеїнази. Ïх регуляторна фрункція здійснюється за реакціями двох типів: повне розщеплення білків до амінокислот і лімітований протеоліз. Найбільш цікавим для дослідження серед різних інгібіторів плазми крові $€ \alpha_{1}$-інгібітор протеїназ, оскільки близько 90 \% трипсинінгібіторної активності плазми припадає на його частку.

Іншим важливим інгібітором протеїназ $є$ $\alpha_{2}$-макроглобулін, який утворює комплекси 3 протеїназами всіх класів: сериновими, тіоловими, металозалежними та кислими. Він здатен пригнічувати активність більшості протеїназ широкого спектра дії. Беручи до уваги важливу роль $\alpha_{2}$-МГ у регуляції і модифікації активності протеолітичних систем крові й тканин, дослідження рівнів цього білка стали широко використовувати в клініці [5].

Ряд дослідників встановив захисну дію йодовмісних тиреоїдних гормонів при стресі, які реалізуються в результаті їх взаємодії 3 клітинним геномом, що призводить до стимуляції локальних стрес-лімітуючих систем - білків теплового шоку й антиоксидантних фрерментів [11-14]. Однак роль йодовмісних гормонів щитоподібної залози в змінах системи протеолізу, викликаних стресом, досліджено недостатньо

Зважаючи на це, метою дослідження було встановити особливості функціонування системи протеїнази/інгібітори протеїназ за умов іммобілізаційного стресу на тлі зниження рівня йодовмісних гормонів щитоподібної залози.

МЕТОДИ ДОСЛІДЖЕННЯ. ДЛЯ вИвчення особливостей перебігу стрес-реакції на тлі гіпотиреозу (ГТ) використовували білих щурів-самців лінії Вістар, яких утримували на стандартному раціоні віварію при вільному доступі до води відповідно до вимог Правил проведення робіт з використанням експериментальних тварин та Європейської конвенції про захист хребетних тварин, що використовуються для дослідних та інших наукових цілей (Страсбург, 1986) [15, 16]. У кожну експериментальну групу методом випадкової вибірки включено по 10 тварин масою (210 20$)$ г. Усього в дослідженні використано 84 тварини, однак унаслідок загибелі впродовж експерименту на момент евтаназії було 80 щурів.

Гіпотиреоз моделювали, щоденно вводячи тваринам per os за допомогою зонда фрармакопейний тиреостатик мерказоліл (“Здоров'я", Україна) у дозі 25 мг/кг протягом 21-ї доби [17]. Повноту досягнення гіпотиреозу контролювали шляхом визначення концентрації трийодтироніну і тироксину в сироватці крові, а також за динамікою маси тварин та їх рухової активності.

Вплив гіпотиреозу на перебіг іммобілізаційного стресу вивчали на моделі іммобілізаційного стресу [11]. Гострий іммобілізаційний стрес (ГІС) моделювали шляхом прив'язування піддослідних щурів у положенні на спині за 4 кінцівки без обмеження рухомості голови тривалістю 3 год. Дослідження проводили через 2 (стадія тривоги) та 48 год (стадія резистентності) після завершення дії стресорного фрактора. Хронічний іммобілізаційний стрес (XIC), що є аналогом стадії виснаження, моделювали тим же методом, який повторювали протягом 5 діб. Дослідження проводили через 2 год після останнього моделювання [11].

Експериментальних тварин поділили на 8 груп:

- інтактні тварини, яким перорально вводили дистильовану воду протягом 21-ї доби;

- тварини, яким моделювали гіпотиреоз шляхом перорального введення мерказолілу в дозі 25 мг/кг протягом 21-ї доби;

- тварини, яким моделювали гострий іммобілізаційний стрес і проводили евтаназію на стадії тривоги (2 год);

- тварини, яким моделювали гострий іммобілізаційний стрес і проводили евтаназію на стадії резистентності (48 год);

- тварини, яким моделювали гострий іммолізіційний стрес на тлі попередньо змодельованого гіпотиреозу (стадія тривоги);

- тварини, яким моделювали гострий іммолізіційний стрес на тлі попередньо змодельованого гіпотиреозу (стадія резистентності);

- тварини, яким моделювали хронічний іммобілізаційний стрес;

- тварини, яким моделювали хронічний іммобілізаційний стрес на тлі попередньо змодельованого гіпотиреозу. 
Для дослідження використовували сироватку крові та гомогенат печінки. Тварин декапітували під тіопенталовим наркозом через 2 i 48 год від моменту завершення одноразової іммобілізації та через 2 год від моменту завершення моделювання хронічного іммобілізаційного стресу.

Вміст загального тироксину $\left(\mathrm{T}_{4}\right)$ і загального трийодтироніну $\left(\mathrm{T}_{3}\right)$ у сироватці крові визначали імунофллуоресцентним методом із використанням стандартних тест-наборів "Immulite 1000". Концентрацію гормонів виражали в пмоль/л.

Загальну протеолітичну активність плазми крові визначали за лізисом азоальбуміну, азоказеїну й азоколу, використовуючи набір реактивів "Simko Ltd" (Україна), методом [1], принцип якого полягає в тому, що при інкубації білкових азосполук у присутності активаторів та інгібіторів протеолізу, які містяться у тканинах, відбувається лізис азоальбуміну (розпад низькомолекулярних протеїнів), азоказеїну (розпад високомолекулярних протеїнів) та азоколагену (колагеноліз), інтенсивність якого оцінювали за ступенем забарвлення інкубаційного середовища на спектрофотометрі СФ-46 при довжині хвилі 440 нм. Протеолітичну активність виражали в одиницях екстинкції на 1 мл плазми за 1 год.

Вміст $\alpha_{2}-\mathrm{MГ} \mathrm{у} \mathrm{сироватці} \mathrm{крові} \mathrm{визначали}$ методом, принцип якого полягає в тому, що він утворює з трипсином активний комплекс, який $\epsilon$ нечутливим до дії інгібітора з бобів сої. Для виконання методики використовували трипсин ("Spofa”, Чехія). Концентрацію $\alpha_{2}-\mathrm{MГ} \mathrm{визначали}$ за калібрувальним грасріком, в якому по осі абсцис відкладали кількість трипсину, а по осі ординат - оптичну щільність проб, в яких відбувся гідроліз N-бензоїл-DL-аргінін-пара-нітроаніліду (БАПНА) відповідною концентрацією трипсину. Концентрацію $\alpha_{2}$-МГ у сироватці крові виражали в г/л [5].

Вміст $\alpha_{1}-І П$ у сироватці крові визначали методом, що базується на його здатності пригнічувати гідроліз трипсином БАПНА. Водночас трипсин у комплексі з $\alpha_{2}$-МГ здатний розщеплювати БАПНА. Вміст $\alpha_{1}-$-П визначали за різницею між відомою кількістю трипсину і кількістю фрерменту, що залишився після його взаємодії з інгібіторами плазми. Вміст цього інгібітора визначали за калібрувальним грасріком, в якому по осі абсцис відкладали кількість трипсину (1-10 мкг), а по осі ординат - оптичну щільність проб, в яких відбувся гідроліз БАПНА відповідною концентрацією трипсину. Вміст $\alpha_{1}-І$ ІП у сироватці крові виражали в мкмоль/л [8].

Розраховували індекс протеолізу, що відображає напруженість або "керованість" протеолітичних процесів, як відношення загальної про- теолітичної активності до сумарної інгібіторної ємності (сума активності $\alpha_{1}-$ ІП і $\alpha_{2}-\mathrm{MГ)} \mathrm{[7].}$

Для приготування гомогенату тканину печінки розтирали за допомогою гомогенізатора при $4^{\circ} \mathrm{C}$ і суспендували в 9 об'ємах 0,25 М розчину цукрози з 0,001 M Na 2 ЕДТА (pH 7,4). Сполучнотканинні елементи, які залишились у середовищі, видаляли шляхом центрифругування (1000 об./хв протягом 3 хв) при охолодженні. Надосадову частину гомогенату печінки використовували для досліджень. Загальну активність катепсину D y гомогенаті тканини печінки визначали за методом Дингла в модифрікації [10]. Активність фрерменту виражали в мкМ тирозину/(мг білка.год).

Статистичну обробку цисрових даних здійснювали за допомогою програмного забезпечення Excel i STATISTICA з використанням параметричних та непараметричних методів оцінки отриманих даних. Для всіх показників розраховували значення середньої арифметичної вибірки (М), ії дисперсії і помилки середньої (m). Достовірність різниці значень між незалежними кількісними величинами визначали при нормальному розподілі за t-критерієм Стьюдента, в інших випадках - за допомогою U-критерію МаннаУїтні (достовірними вважали відмінності при $p<0,05)$.

РЕЗУЛЬТАТИ Й ОБГОВОРЕННЯ. 3 МеТОЮ оцінки фрункціонального стану щитоподібної залози у тварин, яким моделювали гіпотиреоз, визначали концентрацію тиреоїдних гормонів у крові. Концентрація $\mathrm{T}_{3}$ у здорових щурів складала $(5,96 \pm 0,22)$ пмоль/л, а у тварин, яким вводили мерказоліл, показник був знижений у 2,7 раза і становив $(2,19 \pm 0,21)$ пмоль/л. Концентрація $\mathrm{T}_{4}$ в інтактних щурів складала $(10,16 \pm 0,69)$ пмоль/л, а після введення мерказолілу зменшилась у 2,4 раза від показника інтактних тварин і становила $(4,27 \pm 0,28)$ пмоль/л. Ми спостерігали також суб'єктивні ознаки гіпотиреозу: зменшення рухомості, інтенсивніше, ніж в інтактних тварин, зростання маси тіла, зміни шерсті. Це вказує на розвиток у тварин явищ гіпотиреозу внаслідок уведення мерказолілу в дозі 25 мг/кг протягом 21-ї доби.

Показники протеолітичної активності сироватки крові в щурів, яким протягом 21-ї доби вводили мерказоліл, були меншими, ніж у тварин без змодельованої патології, однак лише стосовно лізису азоальбуміну це зниження було достовірним. При моделюванні гострого іммобілізаційного стресу динаміка протеолітичної активності змінювалась залежно від стадії патологічного процесу. Так, лізис азоальбуміну на стадії тривоги був достовірно вищим від показника щурів без змодельованої патології і складав 
145,5 \% від нього. Аналогічні зміни відмічено і стосовно лізису азоказеїну та азоколу. Зокрема, показник лізису азоказеїну на цій стадії становив 132,6 \%, а азоколу - 143,9 \% від рівня тварин, яким патологічних станів не моделювали, в обох випадках різниця між показниками була достовірною. На стадії резистентності показник лізису азоальбуміну нормалізувався і лише на 10,3 \% перевищував рівень щурів без змодельованої патології. Зміни показників лізису азоказеїну та азоколу мали аналогічну спрямованість і через 48 год після моделювання ГІС складали, відповідно, 111,1 та 106,6 \% від показників тварин 1-ї групи, достовірно не відрізняючись від них. Моделювання XIC спричинило значно відчутніші зміни показників протеолітичної активності порівняно з моделюванням ГІС. Зокрема, лізис азоальбуміну в щурів цієї групи перевищував показник тварин без змодельованої патології в 1,7 раза, лізис азоказеїну - в 1,4 раза, азоколу в 1,6 раза. Зміни були достовірними відносно тварин 1-ї групи.

Отже, протеолітична активність сироватки крові евтиреоїдних тварин з іммобілізаційним стресом змінюється залежно від стадії стресу: зростає на стадії тривоги, нормалізується на стадії резистентності з подальшим прогресивним підвищенням на стадії виснаження (табл. 1).

Моделювання ГІС тваринам, яким попередньо змоделювали гіпотиреоз, призводило до більш виражених змін протеолітичної активності сироватки крові. Лізис азоальбуміну на стадії тривоги у тварин цієї групи перевищував рівень щурів без змодельованої патології в 1,6 раза і був на 17,4 \% більшим, ніж на відповідній стадії в евтиреоїдних тварин. Лізис азоказеїну був більшим від рівня евтиреоїдних тварин на 11,1 \%, перевищуючи показник щурів 1-ї групи в 1,4 раза. Аналогічну спрямованість мав також лізис азоколу - показник був на 24,4 \% більшим, ніж в евтиреоїдних тварин, перевищуючи рівень щурів без змодельованої патології в 1,7 раза.

На стадії резистентності, на відміну від евтиреоїдних тварин, не спостерігали нормалізації протеолітичної активності. Зокрема, лізис азоальбуміну був більшим від рівня щурів без змодельованої патології в 1,5 раза, перевищуючи аналогічний показник евтиреоїдних тварин на 41,5 \%. Лізис азоказеїну був майже аналогічним до показника азоальбуміну, а лізис азоколу був ще більш вираженим у тварин цієї групи, перевищуючи в 1,8 раза рівень щурів без змодельованої патології і на 73,8 \% - відповідний показник евтиреоїдних тварин на цій стадії стресу.

Найбільш виражені зміни протеолітичної активності ми спостерігали у тварин з гіпотиреозом на стадії виснаження. Лізис азоальбуміну у тварин цієї групи перевищував рівень щурів без змодельованої патології в 1,8 раза і був на 19,8 \% більшим, ніж в евтиреоїдних тварин відповідної групи. Лізис азоказеїну був дещо меншим - перевищення стосовно тварин 1-ї групи становило 1,6 раза, що на 16,1 \% більше, ніж у щурів 3 нормальним вмістом тиреоїдних гормонів. Водночас лізис азоколу був найвищим - 194 \% від показника щурів 1-ї групи і на 31,7 \% більше, ніж в евтиреоїдних тварин із XIC.

Отже, за умов попередньо змодельованого гіпотиреозу показники протеолітичної активності сироватки крові достовірно перевищують аналогічні показники евтиреоїдних тварин, причому їх відновлення на стадії резистентності, яке спостерігають у щурів з нормальним рівнем йодовмісних гормонів щитоподібної залози, не відбувається за умов гіпотиреозу (табл. 1).

Вміст білкових інгібіторів плазми крові також зазнавав виражених змін (табл. 2). Встановлено достовірне підвищення інгібіторного потенціалу

Таблиця 1 - Динаміка показників протеолітичної активності сироватки крові щурів з іммобілізаційним стресом на тлі гіпотиреозу $(\mathrm{M} \pm \mathrm{m})$

\begin{tabular}{|c|c|c|c|c|}
\hline & \multirow[b]{2}{*}{ Група тварин } & \multicolumn{3}{|c|}{ Показник } \\
\hline & & $\begin{array}{c}\text { лізис } \\
\text { азоальбуміну, } \\
\text { мл }^{-1} \cdot \text { год }^{-1}\end{array}$ & $\begin{array}{c}\text { лізис } \\
\text { азоказеїну, } \\
\text { мл }^{-1} \cdot \text { год }^{-1}\end{array}$ & $\begin{array}{c}\text { лізис } \\
\text { азоколу, } \\
\text { мл }^{-1} \cdot \text { год }^{-1}\end{array}$ \\
\hline \multicolumn{2}{|l|}{ Інтактні, $\mathrm{n}=12$} & $2,53 \pm 0,12$ & $2,24 \pm 0,13$ & $0,82 \pm 0,10$ \\
\hline \multicolumn{2}{|l|}{ Гіпотиреоз, n=12 } & $2,11 \pm 0,07^{*}$ & $1,86 \pm 0,08$ & $0,75 \pm 0,09$ \\
\hline \multirow{3}{*}{$\begin{array}{l}\text { Іммобілізаційний } \\
\text { стрес }\end{array}$} & ГІС (стадія тривоги), n=10 & $3,68 \pm 0,09 *$ & $2,97 \pm 0,11^{*}$ & $1,18 \pm 0,07^{\star}$ \\
\hline & ГІС (стадія резистентності), n=10 & $2,79 \pm 0,11$ & $2,49 \pm 0,09$ & $0,87 \pm 0,09$ \\
\hline & XIC (стадія виснаження), n=9 & $4,17 \pm 0,14^{*}$ & $3,18 \pm 0,12^{*}$ & $1,33 \pm 0,12^{*}$ \\
\hline \multirow{3}{*}{$\begin{array}{l}\text { ГТ+ } \\
\text { іммобілізаційний } \\
\text { стрес }\end{array}$} & ГІС (стадія тривоги), n=10 & $4,12 \pm 0,12^{\star \#}$ & $3,22 \pm 0,11^{\star \#}$ & $1,38 \pm 0,11^{\star \#}$ \\
\hline & ГІС (стадія резистентності), n=10 & $3,84 \pm 009^{\star *}$ & $3,44 \pm 0,13^{\star \#}$ & $1,47 \pm 0,13^{\star \#}$ \\
\hline & XIC (стадія виснаження), n=7 & $4,67 \pm 1,13^{\star \#}$ & $3,54 \pm 0,12^{\star \#}$ & $1,59 \pm 0,12^{\star \#}$ \\
\hline
\end{tabular}

Примітки. Тут і в таблиці 2:

1. * - зміни показників евтиреоїдних і гіпотиреоїдних тварин з гострим та хронічним стресом достовірні відносно показників інтактних тварин $(p<0,05)$.

2. \# - зміни показників гіпотиреоїдних тварин з гострим і хронічним стресом достовірні відносно показників евтиреоїдних тварин на відповідні доби дослідження $(\mathrm{p}<0,05)$. 
Таблиця 2 - Динаміка показників інгібіторів протеаз сироватки крові та катепсину D печінки щурів з іммобілізаційним стресом на тлі гіпотиреозу (M士m)

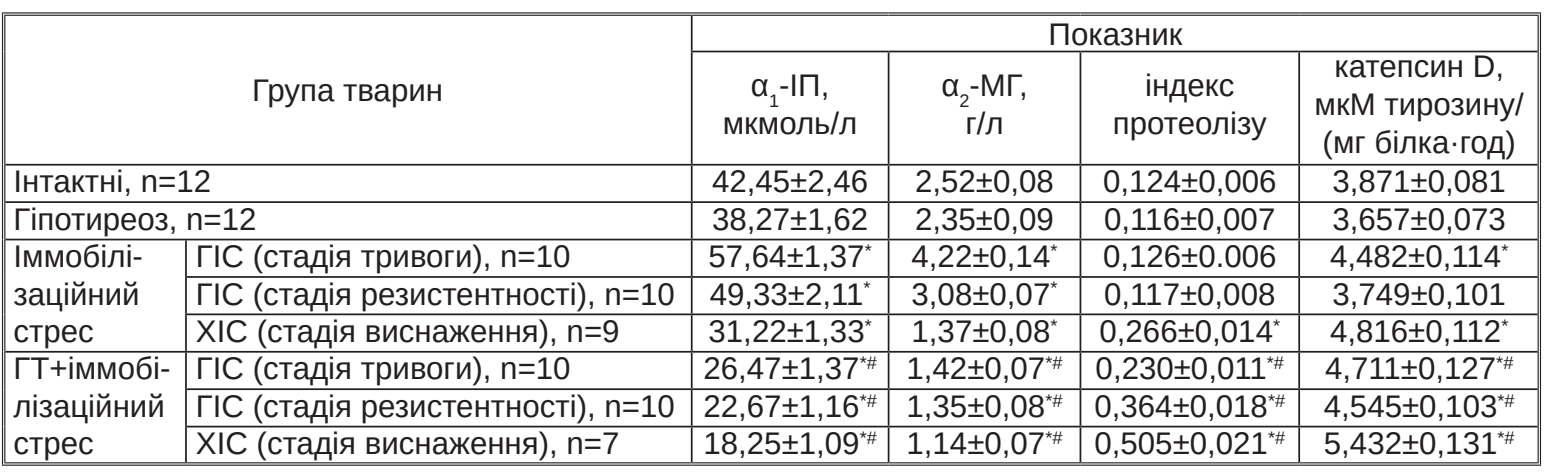

крові евтиреоїдних тварин з ГІС, в основному за рахунок збільшення концентрації $\alpha_{2}-\mathrm{MГ}$, яка зросла в 1,7 раза, на стадії тривоги. Щодо $\alpha_{1}-1 П$, то його концентрація теж зросла, однак дещо менше - в 1,4 раза порівняно зі щурами без змодельованої патології. Виражене збільшення вмісту $\alpha_{2}$-МГ може бути зумовлене його підвищеним продукуванням паралельно 3 гіперпродукуванням інших гострофразових білків у відповідь на дію стресорного чинника. Крім того, зростання активності основних білкових інгібіторів можна розцінювати як неспецифічну захисну реакцію організму на посилений протеоліз та запуск фозіологічних процесів адаптації у відповідь на підвищення протеолітичної активності крові. Таке збільшення інгібіторного потенціалу, поряд із зростанням протеолітичної активності, суттєво не відобразилося на значенні індексу протеолізу в цей період патологічного процесу. На стадії тривоги в щурів з нормальною фуункцією щитоподібної залози мало місце відновлення інгібіторного потенціалу порівняно з попереднім терміном дослідження. Концентрація $\alpha_{1}-$ ІІ перевищувала рівень тварин 1-ї групи на 16,2 \%, а $\alpha_{2}$-МГ - на 22,2 \%. Однак, зважаючи на зменшення в цей період протеолітичної активності крові, індекс протеолізу навіть дещо знизився і становив 94,3 \% від показника щурів 1-ї групи. За умов моделювання XIC вміст білкових інгібіторів у сироватці крові суттєво зменшився. Концентрація $\alpha_{1}$-ІП складала 73,5 \% стосовно тварин 1-ї групи, а $\alpha_{2}-\mathrm{MГ}-54,4 \%$, що вказувало на виснаження антипротеазних резервів крові. Це призводило до активації процесів протеолізу, про що свідчило достовірне зростання індексу протеолізу в 2,1 раза.

Моделювання іммобілізаційного стресу на тлі гіпотиреозу вказує на суттєвий зсув співвідношення протеази/інгібітори протеаз у бік переважання процесів протеолізу. Вже на стадії тривоги вміст обох ключових інгібіторів протеолізу достовірно знижувався стосовно як щурів без змодельованої патології, так і евтиреоїдних тварин зі стресом. Зокрема, концентрація $\alpha_{1}-$ ІІ становила $62,4 \%$, а $\alpha_{2}$-МГ - 56,3 \% від рівня щурів 1-ї групи, достовірно відрізняючись від аналогічних показників евтиреоїдних тварин 3 ГІС - у 2,2 та 2,9 раза відповідно. Це призвело до суттєвого зростання індексу протеолізу - в 1,9 раза порівняно зі щурами 1-ї групи та в 1,8 раза порівняно з евтиреоїдними тваринами.

На стадії резистентності, на відміну від тварин з нормальним рівнем йодовмісних гормонів щитоподібної залози, ми відмітили подальше зниження інгібіторної активності крові. Концентрація $\alpha_{1}-$ ІІ становила 53,4 \%, а $\alpha_{2}-\mathrm{MГ}-53,6 \%$ від рівня щурів без змодельованої патології, водночас достовірно відрізняючись від аналогічних показників евтиреоїдних тварин - у 2,2 і 2,3 раза відповідно. Індекс протеолізу зростав ще більше і перевищував показник щурів 1-ї групи у 2,9 раза, а евтиреоїдних тварин - у 3,1 раза.

На стадії виснаження, за умов хронічного іммобілізаційного стресу, інгібіторний потенціал крові ще більше знижувався. Зокрема, концентрація $\alpha_{1}-І$ ст становила 43,0 \%, а $\alpha_{2}-\mathrm{MГ}-45,2 \%$ від рівня щурів 1-ї групи. Незважаючи на те, що в евтиреоїдних тварин за цих умов дані показники також знижувалися, зменшення у тварин 3 гіпотиреозом було значно суттєвішим: стосовно $\alpha_{1}-$ ІІ - в 1,7 раза, а щодо $\alpha_{2}-\mathrm{MГ} \mathrm{-} \mathrm{в} \mathrm{1,2} \mathrm{раза.} \mathrm{Це}$ призвело до достовірного, порівняно зі щурами без змодельованої патології та евтиреоїдними тваринами з XIC, зростання індексу протеолізу в 4,1 і 1,9 раза відповідно (табл. 2).

Дослідження загальної активності маркерного фрерменту лізосомального матриксу - катепсину D показало, що при гіпотиреозі вона зменшується. Моделювання ГІС призвело до достовірного зростання загальної активності катепсину D на стадії тривоги на 15,8 \% 3 подальшим ії зниженням на стадії резистентності до 96,8 \% відносно щурів без змодельованої патології, що вказувало на стабілізацію лізосомальних мембран у цей період патологічного 
процесу. На стадії виснаження, при моделюванні XIC, активність катепсину D суттєво підвищувалась порівняно з попереднім терміном спостереження і становила 124,4 \% від рівня тварин 1-ї групи. У щурів з гіпотиреозом ми спостерігали достовірне її зростання на всіх стадіях патологічного процесу. Зокрема, на стадії тривоги вона становила 121,7 \% від рівня щурів без змодельованої патології і була на 6,1 \% вищою від показника евтиреоїдних тварин на цій стадії патологічного процесу. На стадії резистентності показник складав 117,4 \% від рівня щурів 1-ї групи, що на 20,6 \% більше, ніж у евтиреоїдних тварин, на стадії виснаження - 140,3 \%, що також вище від показника евтиреоїдниих тварин на $15,9 \%$.

ВИСНОВОК. На тлі гіпотиреозу спостерігають інтенсивніше, ніж у евтиреоїдних тварин, зростання протеолітичної активності крові на фроні пригнічення антипротеазної активності та збільшення проникності лізосомальних мембран.

\section{СПИСОК ЛІТЕРАТУРИ}

1. Веремеенко К. Н. Протеолиз в норме и при патологии / К. Н. Веремеенко, О. П. Голобородько, А. И. Кизим. - К. : Здоров'я, 1988. - 200 с.

2. Кресюн В. Й. Особливості зрушень стану протеїназно-інгібіторної системи за умов розвитку експериментального алергічного альвеоліту і шляхи його корекції / В. Й. Кресюн, Н. Г. Семенців, М. С. Регеда // Одес. мед. журн. - 2009. - № 3 (113). - С. 35-37.

3. Криницька І. Я. Стан протеїназо-інгібіторної системи крові та бронхоальвеолярного змиву у щурів з модельованим гепатопульмональним синдромом / І. Я. Криницька // Заг. патологія та патологічна фрізіологія. - 2012. - 7, № 4. - С. 92-97.

4. Швець В. І. Зміни тканинного протеолізу при інтоксикації білих щурів малими дозами важких металів / В.І.Швець, В. Л. Кісілюк, І. Д. Шкробанець // Клініч. та експерим. патологія. - 2009. - 8, № 4 (30). С. 87-89.

5. Универсальный регулятор - $\alpha_{2}$-макроглобулин / Н. А. Зорин, В. Н. Зорина, Р. М. Зорина, В. Г. Левченко // Клинич. лаб. диагностика. - 2004. - № 11. C. $18-21$.

6. Sousa G. A. Identification of 491 proteins in the tear fluid proteome reveals a large number of proteases and protease inhibitors / G. A. Sousa, L. M. F. Godoy, M. Mann // Genome Biol. - 2006. - 7, No. 8. - P. 72.

7. Дедуль М. И. Система протеолиза в сыворотке крови и перитонеальной жидкости при хирургическом лечении больных эндометриозом / М. И. Дедуль, Л. Е. Радецкая, Л. Н. Кирпиченок // Новости хирургии. - 2006. - 14, № 3. - С. 74-80.

8. Карягина И. Ю. Использование метода комплексного определения активности трипсиноподобных протеиназ, $\alpha_{1}$-антитрипсина и $\alpha_{2}$-макроглобулина в гастроэнтерологической клинике / И. Ю. Карягина, Р. А. Зарембский, М. Д. Балябина // Лаб. дело. 1990. - № 2. - C. 10-13.

9. Биоэнергетика клетки. Химия патологических процессов / под ред. В. Ю. Сереброва, Г. А. Сухановой. - Томск : СГМУ, 2008. - 180 с.
10. Подунай Ю. А. Возрастная динамика активности катепсинов и содержания среднемолекулярных пептидов в мышцах морского ерша / Ю. А. Подунай, И. Н. Залевская, И. И. Руднева // Ученые записки Таврического нац. ун-та им. В. И. Вернадского. Серия "Биология, химия". - 2009. - 22 (61), № 4. C. $128-134$

11. Бондаренко С. Н. Влияние различных методик стрессирования и адаптации на поведенческие и соматические показатели у крыс / С. Н. Бондаренко, Н.А.Бондаренко, Е. Б. Манухина // Бюлл. эксперим. биологии и медицины. - 1999. - 128, № 8. С. 157-160.

12. Данилкина О. П. Физиология стресса животных : метод указания / О. П. Данилкина ; Краснояр. гос. аграр. ун-т. - Красноярск, 2016. - 32 с.

13. Паєнок О. С. Процеси пероксидного окиснення ліпідів і рівень ендогенної інтоксикації у вагітних із тиреопатіями / О. С. Паєнок, М. О. Костів // Експерим. та клініч. фрізіологія та біохімія. - 2012. - № 1. C. 97-101.

14. Роль локальных стресс-лимитирующих систем миокарда в протекторном кардиальном эффректе малых доз тиреоидных гормонов при иммобилизационном стрессе у крыс / И. Ю. Малышев, Л. Ю. Голубева, А. П. Божко, И. В. Городецкая // Росс. фризиол. журн. - 2000. - 86, № 1. - С. 62-67.

15. Кожем'якін Ю. М. Науково-практичні рекомендації з утримання лабораторних тварин та роботи 3 ними / Ю. М. Кожем'якін. - К. : Авіцена, 2002. - 155 с.

16. European convention for the protection of vertebrate animals used for experimental and other scientific purposes. - Council of Europe. Strasbourg. - 1986. No. $123 .-52 \mathrm{p}$.

17. Ром-Бугославська О. С. Доклінічне вивчення тиреостатичних та тиреоїдстимулюючих засобів / О. С. Ром-Бугославська, Т. С. Божко, І.В.Комарова // Доклінічні дослідження лікарських засобів : метод. рек. - К., 2001. - С. 409-420. 


\section{REFERENCES}

1. Veremeyenko, K.N., Goloborodko, O.P., \& Kizim, A.I. (1988). Proteoliz v norme i pri patologii [Proteolysis in health and disease]. Kyiv: Zdorovia [in Russian].

2. Kresiun, V.Y., Sementsiv, N.H., \& Reheda, M.S. (2009). Osoblyvosti zrushen stanu proteinazno-inhibitornoi systemy za umov rozvytku eksperymentalnoho alerhichnoho alveolitu i shliakhy yoho korektsii [Features of shifts of the proteinase-inhibitory system under the conditions of development of experimental allergic alveolitis and ways of its correction]. Odeskyi medychnyi zhurnal - Odesa Medical Journal, 3 (113), 35-37 [in Ukrainian].

3. Krynytska, I.Ya. (2012). Stan proteinazo-inhibitornoi systemy krovi ta bronkhoalveoliarnoho zmyvu u shchuriv z modelovanym hepatopulmonalnym syndromom [The state of the proteinase-inhibitor system of blood and bronchoalveolar wash in rats with simulated hepatopulmonary syndrome]. Zahalna patolohiia ta patolohichna fiziolohiia - General Pathology and Pathological Physiology, 7, 4, 92-97 [in Ukrainian].

4. Shvets, V.I., Kisiliuk, V.L., \& Shkrobanets, I.D. (2009). Zminy tkanynnoho proteolizu pry intoksykatsii bilykh shchuriv malymy dozamy vazhkykh metaliv [Changes in tissue proteolysis due to intoxication of white rats by small doses of heavy metals]. Klinichna ta eksperymentalna patolohiia - Clinical and Experimental Pathology, 8, 4 (30), 87-89 [in Ukrainian].

5. Zorin, N.A., Zorina, V.N., Zorina, R.M. \& Levchenko, V.G. (2004). Universalnyy regulyator - a2-makroglobulin [Universal regulator - a2-macroglobulin]. Klinicheskaya laboratornaya diagnostika - Clinical Laboratory Diagnostics, 11, 18-21 [in Russian].

6. Sousa, G.A., Godoy, L.M.F., \& Mann, M. (2006). Identification of 491 proteins in the tear fluid proteome reveals a large number of proteases and protease inhibitors. Genome Biol., 7, 8, 72.

7. Dedul, M.I., Radetskaya, L.Ye. \& Kirpichenok, L.N. (2006). Sistema proteoliza v syvorotke krovi i peritonealnoy zhidkosti pri khirurgicheskom lechenii bolnykh endometriozom [The system of proteolysis in the serum and peritoneal fluid in the surgical treatment of patients with endometriosis]. Novosti khirurgii - Surgery News, 14, 3, 74-80 [in Russian].

8. Karyagina, I.Yu., Zarembskiy, R.A. \& Balyabina, M.D. (1990). Ispolzovaniye metoda kompleksnogo opredeleniya aktivnosti tripsinopodobnykh proteinaz, a1-antitripsina i a2-makroglobulina $v$ gastroenterologicheskoy klinike [Using the method of complex determination of activity of trypsin-like proteinases, a1-antitrypsin and a2-macroglobulin in a gastroenterological clinic]. Laboratornoye delo - Laboratory Case, 2, 10-13 [in Russian].

9. Serebrova, V.Yu., \& Sukhanova, G.A. (Ed.). (2008). Bioenergetika kletki. Khimiya patologicheskikh protsessov
[Bioenergy of cells. Chemistry of pathological processes]. Tomsk: SGMU [in Russian].

10. Podunay, Yu.A., Zalevskaya, I.N., \& Rudneva, I.I. (2009). Vozrastnaya dinamika aktivnosti katepsinov i soderzhaniya srednemolekulyarnykh peptidov v myshtsakh morskogo yersha [Age dynamics of cathepsin activity and the content of medium molecular peptides in the muscles of the rock fish]. Uchenyye zapiski Tavricheskogo natsionalnogo universiteta im. V.I. Vernadskogo. Seriya "Biologiya, khimiya" - Scientific notes of the V. I. Vernadsky Tauride National University Series "Biology, Chemistry", 22 (61), 4, 128-134 [in Russian].

11. Bondarenko, S.N., Bondarenko, N.A. \& Manukhina, Ye.B. (1999). Vliyaniye razlichnykh metodik stressirovaniya i adaptatsii na povedencheskiye i somaticheskiye pokazateli u krys [The influence of various stress and adaptation techniques on behavioral and somatic indicators in rats]. Byulleten eksperimentalnoy biologii $i$ meditsiny - Bulletin of Experimental Biology and Medicine, 128, 8, 157-160 [in Russian].

12. Danilkina, O.P. Fiziologiya stressa zhivotnykh [Physiology of stress in animals]. Krasnoyarsk: Krasnoyar. gos. agrar. un-t [in Russian].

13. Payenok, O.S., \& Kostiv, M.O. (2012). Protsesy peroksydnoho okysnennia lipidiv i riven endohennoi intoksykatsii u vahitnykh iz tyreopatiiamy [Processes of peroxide oxidation of lipids and the level of endogenous intoxication in pregnant women with thyropathies]. Eksperymentalna ta klinichna fiziolohiia ta biokhimiia Experimental and Clinical Physiology and Biochemistry, 1, 97-101 [in Ukrainian].

14. Malyshev, I.Yu. (2000). Rol lokalnykh stresslimitiruyushchikh sistem miokarda $v$ protektornom kardialnom effekte malykh doz tireoidnykh gormonov pri immobilizatsionnom stresse $u$ krys [The role of local stress-limiting systems of the myocardium in the protective cardiac effect of low doses of thyroid hormones during immobilization stress in rats]. Rosssiyskiy fiziologicheskiy zhurnal - Russian Physiological Journal, 86, 1, 62-67 [in Russian].

15. Kozhemyakin, Yu.M. (2002). Naukovo-praktychni rekomendatsii z utrymannia laboratornykh tvaryn ta roboty $z$ nymy [Scientific and practical recommendations for the maintenance of laboratory animals and work with them]. Kyiv [in Ukrainian].

16. (1986). European convention for the protection of vertebrate animals used for experimental and other scientific purposes. Council of Europe. Strasbourg, 123, 52.

17. Rom-Buhoslavska, O.S., Bozhko, T.S., \& Komarova, I.V. (2001). Doklinichne vyvchennia tyreostatychnykh ta tyreoid-stymuliuchykh zasobiv. Doklinichni doslidzhennia likarskykh zasobiv: metod. rekomendatsii [Pre-clinical study of thyreostatic and thyroid stimulating agents. Preclinical research of drugs: method. recommendations]. Kyiv [in Ukrainian]. 


\section{СОСТОЯНИЕ СИСТЕМЫ ПРОТЕИНАЗЫ/ИНГИБИТОРЫ ПРОТЕИНАЗ У КРЫС В ДИНАМИКЕ ИММОБИЛИЗАЦИОННОГО СТРЕССА НА ФОНЕ ГИПОТИРЕОЗА}

\section{Резюме}

Вступление. В патогенезе многих патологических состояний важное место занимают нарушения протеиназо-ингибиторной системы. При отсутствии надлежащего контроля за протеолизом развиваются патологические состояния, сопровождающиеся возникновением деструктивных, воспалительных и иммунных реакций. Ряд исследователей установил защитное действие йодсодержащих тиреоидных гормонов при стрессе, которые реализуются в результате их взаимодействия с клеточным геномом, что приводит к стимуляции локальных стресс-лимитирующих систем.

Цель исследования - установить особенности фрункционирования системы протеиназы/ингибиторы протеиназ в условиях иммобилизационного стресса на фоне снижения уровня йодсодержащих гормонов щитовидной железы.

Методы исследования. Гипотиреоз моделировали, ежедневно вводя животным per os mupeостатик мерказолил (“Здоровье", Украина) в дозе 25 мг/ке в течение 21-х суток. Острый иммобилизационный стресс моделировали путем привязывания подопытных крыс в положении на спине за 4 конечности без ограничения подвижности головы продолжительностью 3 ч. Для исследования концентрации йодсодержащих гормонов щитовидной железы, активности протеиназной системы и содержания ингибиторов протеолиза использованы спектрофотометрические и иммуноферментные методы.

Результаты и обсуждение. Исследовано влияние иммобилизационного стресса у крыс с предварительно смоделированным гипотиреозом на показатели протеиназо-ингибиторной системы крови. На стадии тревоги развития стресс-реакции в эутиреоидних животных установлено повышение протеолитической активности крови на фроне увеличения содержания $\alpha_{1}$-ингибитора протеаз и $\alpha_{2}$-макроглобулина, что указывает на усиление антипротеолитического потенциала для сдерживания развития деструкции. На стадии резистентности происходила стабилизация протеолитической активности крови. Однако при длительном стрессе (стадия истощения) она снова достоверно возрастала на фроне снижения активности ингибиторов протеаз, что свидетельствует об истощении защитного ингибиторного резерва. У животных с гипотиреозом на всех стадиях развития стресс-реакции имело место достоверное повышение протеолитической активности крови, причем показатели ингибиторов протеаз достоверно уменьшались. Это приводило к резкому возрастанию индекса протеолиза, что происходило на фроне увеличения проницаемости лизосомальных мембран.

Вывод. На фроне гипотиреоза наблюдают более интенсивное, чем в эутиреоидних животных, возрастание протеолитической активности крови на фроне угнетения антипротеазной активности и увеличения проницаемости лизосомальных мембран.

КЛЮЧЕВЫЕ СЛОВА: стресс; гипотиреоз; протеиназо-ингибиторная система; лизосомальные мембраны.

O. E. Lyubovich, I. M. Klishch, A. S. Volska, Kh. I. Kurylo I. HORBACHEVSKY TERNOPIL STATE MEDICAL UNIVERSITY

\section{STATE OF THE PROTEINASE/INHIBITOR SYSTEM IN RATS IN THE DYNAMICS OF IMMOBILIZATIONAL STRESS ON THE BACKGROUND OF HYPOTHYROIDISM}

\section{Summary}

Introduction. In the pathogenesis of many pathological conditions, the violation of the proteinase-inhibitor system is important. In the absence of proper control of proteolysis, a number of pathological conditions, accompanied by the appearance of destructive, inflammatory and immune responses, develops. A number of researchers have established the protective effect of iodine-containing thyroid hormones in stress, realized as a result of their interaction with the cell genome, which leads to stimulation of local stress-limiting systems. 
The aim of the study - to establish the peculiarities of the functioning of the proteinase system/proteinase inhibitors under conditions of immobilization stress against the background of reduction of the level of iodine-containing hormones of the thyroid gland.

Research Methods. Hypothyroidism was modeled daily by the introduction of per os tireostatics of Mercazolil (Zdorovia, Ukraine) at a dose of $25 \mathrm{mg} / \mathrm{kg}$ during the $21^{\text {st }}$ day. Acute immobilization was modeled by binding the experimental rats to the back on the 4 limbs without limiting the mobility of the head for a duration of 3 hours. Spectrophotometric and immuno-enzymatic methods were used to study the concentration of iodine-containing hormones of the thyroid gland, the activity of the proteinase system and the content of proteolytic inhibitors.

Results and Discussion. The effect of immobilization stress in rats with pre-modeled hypothyroidism on the parameters of the proteinase-inhibitory system of blood has been investigated. At the stage of the anxiety of the development of the stress reaction in euthyroid animals, an increase in the proteolytic activity of the blood was observed against the background of an increase in the content of $\alpha 1$-inhibitor proteases and $\alpha 2-m a c r o g l o b u l i n$, indicating an increase in antiprotoitic potential to inhibit the development of degradation. At the stage of resistance there is a stabilization of proteolytic activity of the blood. However, with prolonged stress (depletion stage), the proteolytic activity of blood again significantly increases with the decrease in the activity of protease inhibitors, indicating the depletion of protective inhibitory reserve. In animals with hypothyroidism, at all stages of the development of a stress reaction, there is a significant increase in proteolytic activity of the blood, and the rates of protease inhibitors are significantly reduced. This leads to a sharp increase in the index of proteolysis, which occurs against the background of increased permeability of lysosomal membranes.

Conclusion. Against the background of hypothyroidism, more intense than euthyroid animals, an increase in the proteolytic activity of blood against the backdrop of inhibition of antiprotozoal activity and an increase in the permeability of lysosomal membranes is observed.

KEY WORDS: stress; hypothyroidism; proteinase-inhibitor system; lysosomal membranes.

Отримано 07.08.18

Адреса для листування: І. М. Кліщ, Тернопільський державний медичний університет імені І. Я. Горбачевського, майдан Волі, 1 Тернопіль, 46001, Україна, e-mail: klishch@tdmu.edu.ua. 